\title{
The Mystery of Totality in Mircea Eliade`s A Spiritual Adventure
}

\section{Ana-Maria Fomin ${ }^{*}$}

This paper aims to explore the imaginary universe of Mircea Eliade's A Spiritual Adventure, employing the tools of a transdisciplinary hermeneutics ${ }^{1}$. Following this path, we will attempt to reveal the complex configuration of this literary creation through meanings rooted in the discovery of the outstanding potentialities revealed within totalized human consciousness. This spiritual itinerary implies successive labyrinthine experiences, each of them belonging to a different level of reality, demanding specific instruments of knowledge suited for understanding and unifying the information that camouflages the message of cosmization. Focusing on the architecture of the Eliadean text and its meanings, we will also highlight the correlations identified by the Romanian historian of religions between the creations of the human spirit and the most daring cosmological models promoted by modern science. Through all these observations, we will demonstrate Eliade's interest in revealing the importance of deepening the links between the depths of the human spirit and the continuous movement of the universe. [Article copies available for a fee from The Transformative Studies Institute. E-mail address: journal@transformativestudies.org Website: http://www.transformativestudies.org (C2013 by The Transformative Studies Institute. All rights reserved.]

KEYWORDS: Mircea Eliade, Transdisciplinarity, Levels of Reality, Cosmization, A New Reality Paradigm, A Spiritual Adventure.

\footnotetext{
*Ana-Maria Fomin is a Ph.D. student at "Ştefan cel Mare" University of Suceava, Romania. She has an MA in British Cultural Studies from the University of Bucharest, Faculty of Foreign Languages and Literatures, Romania. Address correspondence to: Ana-Maria Fomin, e-mail: fominana@yahoo.com. Acknowledgments: The author wishes to thank Fevronia Novac, Professors Mac Linscott Ricketts and Ali Zaidi for their helpful suggestions. This paper has been financially supported within the project titled "Doctorate: an Attractive Research Career", contract number POSDRU/107/1.5/S/77946, co-financed by European Social Fund through Sectorial Operational Programme for Human Resources Development 2007-2013.
} 